\title{
PENERAPAN METODE PROBLEM SOLVING DENGAN MEDIA GAMBAR SERI UNTUK MENINGKATKAN HASIL BELAJAR IPS KELAS IV SEKOLAH DASAR
}

\author{
Erwin Putera Permana \\ erwinp@,unpkediri.ac.id \\ Pendidikan Guru Sekolah Dasar \\ Fakultas Keguruan Ilmu Pendidikan \\ Universitas Nusantara PGRI Kediri
}

\begin{abstract}
Based on the observations of researchers in learning social studies found that students were less active in the learning process IPS. Students are less interested in social studies because during social studies only considered as subjects only rote and less emphasis on affective and psychomotor aspects. Teacher-centered learning, teaching methods are less effective, do not use the lesson plan (RPP), do not use the medium of learning, students are less given the opportunity for creativity, students are not encouraged to find a concept but indicated concepts to keep in mind, students easily forget what who had previously remembered because learning is limited to reading a book or listening to an explanation. Consequently the results of social studies is very low, of 33 students, who thoroughly studied only 14 students of completeness criteria 65 . Thus, researchers conducted a study to solve these problems. The purpose of this study were (1) Describe the application of the method of problem solving with the media image series in improving learning outcomes in teaching social studies for class IV SDN Turi 01 Town Blitar, and (2) Describe the improvement of learning outcomes in teaching social studies for class IV SDN Turi 01 Town Blitar. Data collected by observation, observation, document, and test. Results of the study are: (1) an increase in activity of student learning through the application of methods of problem solving, (2) an increase in student learning outcomes through the implementation of the application of problem solving methods, and (3) of 33 students only one of students who have not completed thereafter learning activities for two cycles because of relatively slow learning students.
\end{abstract}

Keywords: Problem Solving Methods, Media Image Series, Results Learning, Learning IPS

ABSTRAK: Berdasarkan observasi peneliti dalam pembelajaran IPS ditemukan bahwa siswa kurang aktif dalam proses belajar mengajar IPS. Siswa kurang tertarik dengan mata pelajaran IPS karena selama ini mata pelajaran IPS hanya dianggap sebagai mata pelajaran hafalan saja dan kurang menekankan pada aspek afektif dan psikomotor. Pembelajaran berpusat pada guru, metode mengajar kurang efektif, tidak menggunakan rencana pelaksanaan pembelajaran (RPP), tidak menggunakan media pembelajaran, siswa kurang diberi kesempatan untuk berkreatifitas, siswa tidak diajak untuk menemukan konsep tetapi ditunjukkan konsep yang harus selalu diingat, siswa mudah lupa dengan apa yang sudah diingat sebelumnya karena pembelajaran terbatas pada kegiatan membaca 
Erwin Putera Permana, Penerapan Metode Problem Solving...

\begin{abstract}
buku atau mendengar penjelasan. Akibatnya hasil belajar IPS sangat rendah yaitu dari 33 siswa, yang tuntas belajar hanya 14 siswa dari kriteria ketuntasan 65 . Sehingga peneliti melakukan penelitian untuk memecahkan permasalahan tersebut. Tujuan penelitian ini adalah (1) Mendeskripsikan penerapan metode problem solving dengan media gambar seri dalam meningkatkan hasil belajar dalam pembelajaran IPS bagi kelas IV SDN Turi 01 Kota Blitar, dan (2) Mendeskripsikan peningkatan hasil belajar dalam pembelajaran IPS bagi kelas IV SDN Turi 01 Kota Blitar. Data dikumpulkan dengan pengamatan, observasi, dokumen, dan tes. Hasil penelitian adalah: (1) terjadi peningkatan aktivitas belajar siswa melalui penerapan metode problem solving, (2) terjadi peningkatan hasil belajar siswa melalui penerapan penerapan metode problem solving, dan (3) dari 33 siswa hanya satu siswa yang belum tuntas setelah dilaksanakan kegiatan pembelajaran selama dua siklus karena tergolong siswa lambat belajar.
\end{abstract}

Kata kunci: Metode Problem solving, Media Gambar Seri, Hasil Belajar, Pembelajaran IPS,

\title{
PENDAHULUAN
}

Pendidikan adalah usaha sadar dan terencana untuk mewujudkan suasana belajar dan proses pembelajaran agar siswa secara aktif mengembangkan potensi dirinya untuk memiliki kekuatan spiritual keagamaan, pengendalian diri, kepribadian, kecerdasan, akhlak mulia, serta keterampilan yang diperlukan dirinya, masyarakat, bangsa dan negara (Sagala, 2010: 3).

Berdasarkan hal tersebut maka pendidikan harus berkualitas artinya dalam pembelajaran siswa harus mengalami proses pembelajaran secara efektif yang bermakna serta menunjukkan adanya tingkat penguasaan terhadap tugas-tugas belajar sesuai dengan sasaran dan tujuan pendidikan. Namun untuk memperoleh pendidikan berkualitas yang mampu meningkatkan hasil belajar sulit ditemukan.

Pembelajaran yang selama ini dilakukan di sekolah oleh guru cenderung menggunakan pembelajaran konvensional. Karena dianggap lebih mudah dan tanpa banyak biaya. Dengan menggunakan metode ceramah tanpa metode inovatif yang lain banyak sekali kelemahan-kelemahan antara lain siswa menjadi bosan, dapat menimbulkan verbalisme, hanya mengandalkan hafalan, informasi yang disampaikan mudah usang, siswa tidak bisa membentuk konsep dan kreatifitas sendiri, hanya mampu berinteraksi satu arah saja yaitu melalui guru kepada siswa sehingga siswa akan merasa dirugikan apabila guru selalu menggunakan metode ceramah tanpa adanya variasi dalam pembelajaran. Hal ini yang terjadi di SDN Turi 01.

Berdasarkan hasil observasi peneliti, siswa kurang aktif dalam proses belajar mengajar IPS. Siswa kurang tertarik dengan mata pelajaran IPS karena selama ini mata pelajaran IPS hanya dianggap sebagai mata pelajaran hafalan saja dan kurang menekankan pada aspek afektif dan psikomotor. Pembelajaran berpusat pada guru, metode mengajar kurang efektif, tidak menggunakan rencana pelaksanaan pembelajaran (RPP), tidak menggunakan media pembelajaran, siswa kurang diberi kesempatan untuk berkreatifitas, siswa tidak diajak untuk menemukan konsep tetapi ditunjukkan konsep 
Erwin Putera Permana, Penerapan Metode Problem Solving...

yang harus selalu diingat, siswa mudah lupa dengan apa yang sudah diingat sebelumnya karena pembelajaran terbatas pada kegiatan membaca buku atau mendengar penjelasan. Akibatnya hasil belajar IPS sangat rendah yaitu dari 33 siswa, yang tuntas belajar hanya 14 siswa dari kriteria ketuntasan 65 .

Guru seharusnya dapat menciptakan pembelajaran yang mampu menarik minat siswa agar memiliki pola pikir konstruktif, kreatif dan memiliki kebebasan untuk menemukan konsep sendiri sehingga konsep yang dimiliki siswa akan mudah diingat. Selain itu guru juga harus dapat mengadakan pembelajaran yang berpusat pada siswa (student centred) karena semakin seringnya keterlibatan siswa dalam kegiatan, maka makin besar baginya untuk mengalami proses belajar.

Pembelajarn dapat efektif dan kreatif maka guru harus bisa menentukan suatu metode, kerena metode adalah suatu cara atau prosedur yang dipakai untuk mencapai tujuan tertentu. Metode pembelajaran adalah cara-cara menyajikan bahan pelajaran kepada siswa untuk tercapainya tujuan yang telah ditetapkan (Fathurrohman, 2009: 55). Dengan demikian, salah satu keterampilan guru yang memegang peranan penting dalam pembelajaran adalah keterampilan memilih metode. Pemilihan metode berkaitan langsung dengan usaha-usaha guru dalam menampilkan pembelajaran yang sesuai dengan situasi dan kondisi sehingga pencapaian tujuan pembelajaran diperoleh secara optimal. Semakin tepat metode yang digunakan oleh guru dalam mengajar, diharapkan semakin efektif pula pencapaian tujuan pembelajaran. Oleh sebab itu, fungsi metode pembelajaran tidak dapat diabaikan karena metode pembelajaran tersebut ikut menentukan berhasil tidaknya suatu pembelajaran.

Ada berbagai macam metode pembelajaran yang cocok diterapkan pada pembelajaran IPS, salah satunya adalah metode problem solving dengan media gambar seri karena metode ini memiliki beberapa keunggulan antara lain: mengarahkan siswa dalam berpikir ilmiah, kritis dan analitis serta siswa akan mampu bertindak aktif dan mandiri dalam menghadapi dunia nyata. Selain itu dukungan media dalam pembelajaran sangatlah penting salah satunya yaitu media gambar seri. Media gambar seri memiliki kelebihan antara lain: memperjelas penyajian pesan agar tidak terlalu verbalisme, mampu mengatasi keterbatasan ruang, waktu dan daya indra, mampu mengatasi sifat pasif siswa sehingga anak akan lebih aktif dan memungkinkan terjadinya interaksi antara siswa dan lingkungan belajar.

\section{METODE}

Pendekatan yang digunakan adalah penelitian kualitatif dengan desain Penelitian Tindakan Kelas (PTK). Dalam penelitian kualitatif, peneliti bertindak sebagai instrumen sekaligus pengumpul data. Instrumen yang digunanakan dalam penelitian ini antara lain tes, lembar observasi, angket dan dokumentasi. Peran peneliti dalam penelitian ini sebagai perencana kegiatan, pelaksana kegiatan, pengumpul data, menganalisis data, dan menyusun hasil laporan. Secara umum, pada siklus PTK terdiri 
Erwin Putera Permana, Penerapan Metode Problem Solving...

atas: planning (perencanaan), acting (tindakan), observing (pengobservasian), dan reflekting (perefleksian). Indikator keberhasilan penelitian tindakan kelas dapat dilihat dari peningkatan hasil belajar siswa sebagai akibat penerapan metode problem solving dengan media gambar seri.

\section{Lokasi dan Waktu Penelitian}

Lokasi penelitian adalah tempat yang digunakan dalam melakukan penelitian untuk memperoleh data yang diinginkan. Penelitian ini bertempat di SDN Turi 01 Kota Blitar.

Waktu penelitian adalah waktu berlangsungnya penelitian atau saat penelitian ini dilangsungkan. Waktu penelitian dimulai dari perencanaan penelitian, pengidentifikasian permasalahan penelitian, pembuatan instrument penelitian, pembuatan proposal penelitian, pelaksanaan penelitian, pengumpulan data penelitian, pengolahan dan analisis data, dan penulisan laporan penelitian. Sejak perencanaan penelitian hingga selesainnya penulisan laporan penelitian ini, diperkirakan memerlukan waktu selama tiga bulan, terhitung sejak bulan Februari sampai dengan bulan April 2014.

\section{Prosedur Penelitian}

Penelitian yang dilakukan menggunakan Penelitian Tindakan Kelas (PTK). Pelaksanaan PTK merupakan proses berdaur (siklus) yang terdiri dari 4 tahap yaitu perencanaan tindakan (planning), pelaksanaan tindakan (action), pengamatan (observation), dan refleksi (reflektion). Berikut ini adalah model spiral penelitian tindakan kelas dari Arikunto (2007: 16).

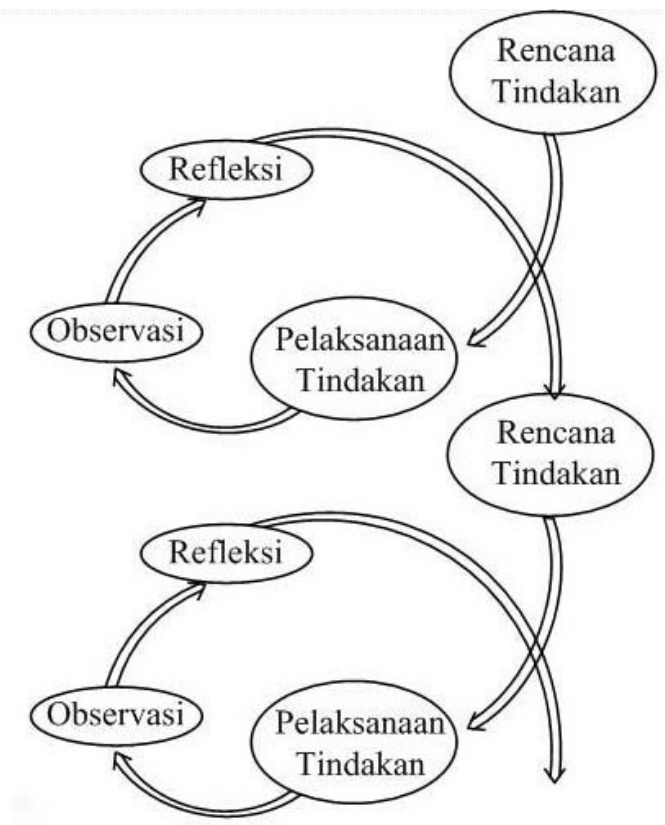

Gambar 1. Spiral Penelitian Tindakan Kelas (Sumber: Arikunto, 2007: 16) 


\section{Tahap-tahap Penelitian}

Pada tahap pelaksanaan ini dilakukan sesuai PTK yang mengacu model spiral penelitian tindakan kelas atau yang biasa disebut siklus. Kegiatan setiap siklus yaitu rencana tindakan, pelaksanaan tindakan, pengamatan, dan refleksi. Berikut ini tahaptahap kegiatan yang dilakukan pada setiap siklus penelitian.

\section{Siklus I}

Penjelasan bagan sebagai berikut.

1) Tahap perencanaan/rancangan

Dalam penelitian ini, peneliti mengidentifikasi masalah pembelajaran. Peneliti melakukan observasi dan melakukan wawancara kepada guru kelas, kemudian melakukan diskusi untuk dapat menemukan masalah pembelajaran untuk mencari pemecahan masalah melalui PTK. Setelah permasalahan pembelajaran teridentifikasi, peneliti menyusun rancangan untuk menentukan langkah-langkah nyata yang akan dilakukan dalam tindakan. Perencanaan tersebut meliputi penyusunan RPP dan membuat instrumen pengamatan untuk membantu merekam fakta yang terjadi selama tindakan berlangsung.

2) Tahap pelaksanaan

Pada tahap ini, rancangan metode dan RPP diterapkan. Rancangan tindakan menjelaskan langkah demi langkah kegiatan yang harus dilakukan guru dan siswa sesuai dengan yang direncanakan. Pada tahap ini guru memberikan stimulus-stimulus berupa pertanyaan agar siswa mengungkapkan pemahaman materi.

3) Tahap pengamatan

Pengamatan dilakukan pada waktu tindakan sedang berlangsung sehingga pengamatan dan tindakan berlangsung pada waktu yang sama. Pada tahap ini, observer dan guru melakukan pengamatan dan mencatat semua hal yang terjadi selama pelaksanaan tindakan berlangsung

4) Tahap refleksi

Tahap ini untuk mengkaji secara menyeluruh tindakan yang telah dilakukan berdasarkan data yang terkumpul kemudian dilakukan evaluasi yang berguna untuk menyempurnakan tindakan berikutnya. Demikian seterusnya sampai masalah yang diteliti dapat terpecahkan secara optimal. Tujuannya adalah untuk menemukan perbaikan-perbaikan yang perlu dilakukan pada proses pembelajaran pada siklus berikutnya. Dalam hal ini adalah hasil belajar siswa pada mata pelajaran IPS. Tahaptahap ini berlaku juga untuk siklus 1 dan siklus 2 .

\section{Instrumen Penelitian}

Instrumen penelitian ini pada dasarnya adalah peneliti itu sendiri. Peneliti menjadi instrumen penelitian karena dalam proses pengumpulan data itulah peneliti akan melakukan adaptasi secara aktif sesuai dengan keadaan yang dihadapi peneliti ketika berhadapan dengan subjek penelitian. Sejalan dengan itu Akbar (2008: 96) menyatakan bahwa meskipun peneliti berperan sebagai instrumen penelitian yang dapat melakukan adaptasi aktif terhadap keadaan subjek yang menjadi penelitian maka 
peneliti juga menggunakan instrumen penelitian yang berupa pedoman observasi, dokumentasi, tes dan wawancara.

Data yang diperlukan dalam penelitian ini meliputi data hasil Hasil Belajar siswa dan data aktivitas siswa. Secara terperinci, perolehan data dijelaskan sebagai berikut:

1. Data penilaian Hasil Belajar diperoleh dari skor tes pada akhir setiap siklus yang direncanakan.

2. Data aktivitas belajar siswa yang berupa keterampilan proses dan sikap diperoleh dari penilaian aspek aspek kerjasama, aspek ide, aspek keaktifan dan aspek komunikatif yang diisi selama proses pembelajaran.

Sumber data dalam penelitian ini adalah siswa kelas IV SDN Turi 01 Kecamatan Gandusari Kabupaten Blitar. Peneliti bertindak sebagai pelaksana tindakan, sedangkan mitra peneliti yaitu guru kelas sebagai pengamat (Observer) tindakan, dan teman sejawat sebagai pengambil dokumentasi.

\section{HASIL}

Data yang diperoleh pada penilitian ini merupakan hasil pelaksanaan pembelajaran yang dilakukan selama dua siklus. Setiap siklus terdiri dari tiga kali pertemuan dengan alokasi pada setiap pertemuan adalah 2 × 35 menit. Uraian pada setiap siklus adalah sebagai berikut.

Pelaksanaan Pembelajaran Siklus I

Tabel 1. Rekapitulasi Data Data penilaian hasil pada Siklus I dalam Menggunakan Metode Problem Solving dengan Media Gambar Seri

\begin{tabular}{cccccccc}
\hline Penilaian & \multicolumn{3}{c}{ Penilaian aktivitas siswa } & \multicolumn{3}{c}{ Penilaian kerja kelompok } & Nilai \\
Hasil & Pert 1 & Pert 2 & Pert 3 & Pert 1 & Pert 2 & Pert 3 & Hasil \\
\hline Rata-rata & 57 & 63 & 63 & 64 & 66 & 69 & 69 \\
Persentase & & & & & & & 64
\end{tabular}

Pada tabel terlihat jelas peningkatan aktivitas siswa dan kerja kelompok menggunakan metode problem solving dengan media gambar seri. Dari penilaian aktivitas siswa, pada pertemuan pertama memperoleh nilai rata-rata klasikal 57, pertemuan kedua memperoleh nilai rata-rata klasikal 63 dan pertemuan ketiga memperoleh nilai rata-rata klasikal 63. Dari penilaian kerja kelompok, pada pertemuan pertama memperoleh nilai rata-rata klasikal 64, pertemuan kedua memperoleh nilai ratarata klasikal 66 dan pertemuan ketiga memperoleh nilai rata-rata klasikal 69. Nilai hasil individu yang diperoleh nilai rata-rata 69 atau 64\% siswa tuntas dari jumlah seluruh siswa. Hal ini menunjukkan bahwa hasil belajar pemahaman konsep ekonomi lebih meningkat dari pra siklus yang hanya memperoleh nilai rata-rata 61,42 atau $42 \%$ siswa tuntas. Hal ini menunjukkan bahwa rata-rata klasikal yang didapat siswa belum memenuhi KKM yang telah direncanakan oleh peneliti yaitu sebesar 75\%. Dan untuk mencapai KKM tersebut perlu adanya tindak lanjut terhadap kegiatan pembelajaran pada siklus II. 


\section{Pelaksanaan Pembelajaran Siklus II}

Tabel 2. Rekapitulasi Data penilaian hasil pada Siklus II dalam Menggunakan Metode Problem Solving dengan Media Gambar Seri

\begin{tabular}{cccccccc}
\hline Penilaian & \multicolumn{3}{c}{ Penilaian aktivitas siswa } & \multicolumn{2}{c}{ Penilaian kerja kelompok } & Nilai \\
Hasil & Pert 1 & Pert 2 & Pert 3 & Pert 1 & Pert 2 & Pert 3 & Hasil \\
\hline Rata-rata & 68 & 69 & 78 & 74 & 79 & 87 & 89 \\
Persentase & & & & & & & 97 \\
\hline
\end{tabular}

Pada tabel terlihat jelas peningkatan aktivitas siswa dan kerja kelompok menggunakan metode problem solving dengan Media Gambar Seri. Dari penilaian aktivitas siswa, pada pertemuan pertama memperoleh nilai rata-rata klasikal 68, pertemuan kedua memperoleh nilai rata-rata klasikal 69 dan pertemuan ketiga memperoleh nilai rata-rata klasikal 78. Dari penilaian kerja kelompok, pada pertemuan pertama memperoleh nilai rata-rata klasikal 74, pertemuan kedua memperoleh nilai ratarata klasikal 79 dan pertemuan ketiga memperoleh nilai rata-rata klasikal 87. Nilai hasil individu yang diperoleh nilai rata-rata 89 atau 97\% siswa tuntas dari jumlah seluruh siswa. Data di atas menunjukkan bahwa nilai individu pemahaman konsep aktivitas ekonomi lebih meningkat dari siklus I yang hanya memperoleh nilai rata-rata 69 atau 64\% siswa tuntas. Hasil pembelajaran pada siklus II telah memenuhi KKM yang telah direncanakan oleh peneliti yaitu sebesar 75. Dan penelitian berhenti pada siklus ini

Tabel 3. Peningkatan Hasil Belajar Individu Siswa Siklus I dan Siklus II

\begin{tabular}{|c|c|c|c|c|c|c|}
\hline \multirow[b]{2}{*}{ No } & \multirow[b]{2}{*}{ Nama Siswa } & \multicolumn{3}{|c|}{ Nilai } & \multicolumn{2}{|c|}{ Keterangan } \\
\hline & & $\begin{array}{c}\text { Pra } \\
\text { Tindakan }\end{array}$ & Siklus I & Siklus II & Tuntas & $\begin{array}{l}\text { Tidak } \\
\text { Tuntas }\end{array}$ \\
\hline 1. & Adi Tri Wahyudi & 49 & 65 & 90 & $\sqrt{ }$ & \\
\hline 2. & Dwi Zulfa Nurisma & 41 & 45 & 65 & & $\sqrt{ }$ \\
\hline 3. & Zudha Eko P & 48 & 65 & 95 & $\sqrt{ }$ & \\
\hline 4. & Zepri & 43 & 55 & 90 & $\sqrt{ }$ & \\
\hline 5. & Kharisma Intan P & 46 & 65 & 100 & $\sqrt{ }$ & \\
\hline 6. & Ventcent Rico & 41 & 60 & 85 & $\sqrt{ }$ & \\
\hline 7. & Anifatus Sholimah & 63 & 60 & 85 & $\sqrt{ }$ & \\
\hline 8. & Asad Abiyyi & 68 & 70 & 90 & $\sqrt{ }$ & \\
\hline 9. & Alandika Putra M & 81 & 80 & 100 & $\sqrt{ }$ & \\
\hline 10. & Alfredo Rizky S & 65 & 65 & 75 & $\sqrt{ }$ & \\
\hline 11. & Apin Surahmi & 60 & 70 & 90 & $\sqrt{ }$ & \\
\hline 12. & Ciptian Rico P & 76 & 85 & 95 & $\sqrt{ }$ & \\
\hline 13. & Devi ira Bayu Oktara & 86 & 90 & 100 & $\sqrt{ }$ & \\
\hline 14. & Dina Mukti P & 73 & 70 & 90 & $\sqrt{ }$ & \\
\hline 15. & Faris Sidik P & 79 & 90 & 100 & $\sqrt{ }$ & \\
\hline 16. & Fauzizah K & 53 & 75 & 90 & $\sqrt{ }$ & \\
\hline 17. & Fika Tri Wijayanto & 60 & 75 & 90 & $\sqrt{ }$ & \\
\hline 18. & Jefri Bayu P & 56 & 65 & 85 & $\sqrt{ }$ & \\
\hline 19. & Muhammad Z & 77 & 90 & 100 & $\sqrt{ }$ & \\
\hline 20. & Muhammad L & 74 & 75 & 100 & $\sqrt{ }$ & \\
\hline
\end{tabular}


Erwin Putera Permana, Penerapan Metode Problem Solving...

\begin{tabular}{|c|c|c|c|c|c|c|}
\hline 21. & Nurhaq F & 68 & 60 & 75 & $\sqrt{ }$ & \\
\hline 22. & Riris S & 43 & 65 & 85 & $\sqrt{ }$ & \\
\hline 23. & Riska Febri L & 58 & 55 & 75 & $\sqrt{ }$ & \\
\hline 24. & Rizanita Putri & 70 & 75 & 100 & $\sqrt{ }$ & \\
\hline 25. & Defi Ratna Sari & 45 & 75 & 100 & $\sqrt{ }$ & \\
\hline 26. & Sugeng Hariono & 51 & 50 & 75 & $\sqrt{ }$ & \\
\hline 27. & Yakhsi Fandana & 77 & 50 & 75 & $\sqrt{ }$ & \\
\hline 28. & Yuni Mualimatun & 70 & 80 & 100 & $\sqrt{ }$ & \\
\hline 29. & Zidan Hadi I & 68 & 60 & 85 & $\sqrt{ }$ & \\
\hline 30. & Ardianto & 63 & 90 & 100 & $\sqrt{ }$ & \\
\hline 31. & Febian Leosis $\mathrm{S}$ & 60 & 60 & 80 & $\sqrt{ }$ & \\
\hline 32. & Fredi Agus P & 61 & 60 & 80 & $\sqrt{ }$ & \\
\hline 33. & Dimas Bayu P & 58 & 80 & 100 & $\sqrt{ }$ & \\
\hline \multicolumn{2}{|r|}{ Jumlah } & 2027 & 2275 & 2945 & 32 & 1 \\
\hline \multicolumn{2}{|r|}{ Rata-rata } & 61 & 69 & 89 & & \\
\hline \multicolumn{2}{|r|}{ Persentase } & $42 \%$ & $64 \%$ & $97 \%$ & & \\
\hline
\end{tabular}

Peningkatan aktivitas belajar siswa kelas IV SDN Turi 01 Kota Blitar pada siklus I dan siklus II dalam tabel di atas diperjelas dalam bentuk diagram batang berikut.

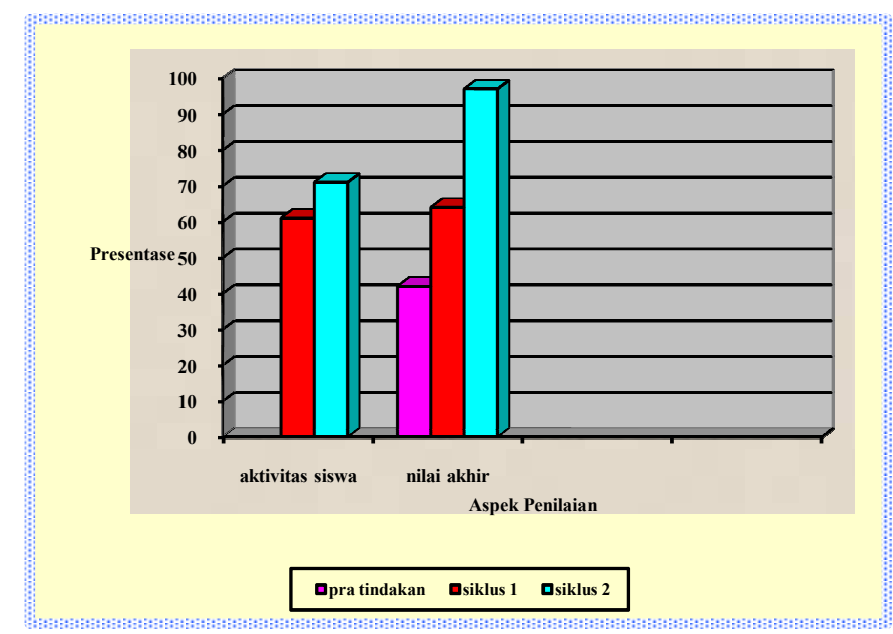

\section{Diagram 1. Peningkatan Hasil Belajar Individu}

Diagram di atas menginformasikan bahwa persentase nilai hasil belajar pemahaman konsep siswa dari siklus I menuju siklus II mengalami peningkatan sebesar 33\%. Dengan demikian dapat disimpulkan bahwa hasil penelitian menunjukkan penerapan metode problem solving dengan Media Gambar Seri dapat meningkatkan hasil belajar aktivitas ekonomi pada siswa kelas IV di SDN Turi 01.

\section{Temuan Penelitian}

\section{a. Temuan Penelitian Siklus 1}

Penerapan metode problem solving dengan media gambar seri belum berjalan sesuai tahap-tahapnya. Siswa belum mampu bekerja kelompok secara maksimal karena siswa jarang dibentuk kerja kelompok oleh guru, siswa belum mampu mengidentifikasi dan membaca peta karena siswa kurang memahami penggunaan peta. Siswa belum bisa menemukan masalah dan hanya bisa membaca permasalahan yang diberikan guru pada 
LKK. Siswa belum bisa menyusun hipotesis pemecahan karena pemahaman siswa pada materi sangat kurang.

\section{b. Temuan Penelitian Siklus 2}

Penerapan metode problem solving dengan media gambar seri siswa sudah mulai mampu bekerja kelompok, sudah mulai mampu menidentifikasi permasalahan sehingga menemukan masalah, siswa sudah mampu memperoleh data, siswa mulai mampu menyusun hipotesis pemecahan walau belum sempurna, dan siswa mulai mampu mengaplikasikan konsep.

\section{PEMBAHASAN}

\section{Penerapan Metode Problem Solving dengan Media Gambar Seri dalam Meningkatan Hasil Belajar IPS Siswa Kelas IV SDN Turi 01 Kota Blitar.}

Berdasarkan pada paparan data, dapat disimpulkan bahwa IPS di kelas IV SDN Turi 01 Kota Blitar menunjukkan bahwa dalam pembelajaran di kelas siswa terlihat bosan dan tidak bersemangat. Hal ini disebabkan beberapa alasan yaitu penggunaan metode ceramah oleh guru kelas, guru hanya mengandalkan buku paket dan LKS dalam pembelajaran, guru tidak memanfaatkan media pembelajaran dan hanya dipasang untuk pajangan, guru tidak mengkondisikan siswa dalam kegiatan kelompok, siswa tidak diberi kesempatan dalam menemukan konsep tetapi diberi konsep untuk dihafal oleh siswa dan siswa cenderung hanya duduk, diam, mendengarkan, mencatat dan tidak ada pertanyaan yang dapat menstimulus siswa dalam mengajukan pendapat sehingga siswa merasa bosan dalam pembelajaran.

Hal tersebut di atas sesuai dengan pendapat yang dikemukakan oleh (Suharjo, 2006). Pembelajaran merupakan sesuatu yang kompleks. Pembelajaran tidak hanya sekedar menyampaikan pesan kepada peserta didik, akan tetapi merupakan aktivitas profesional yang menuntut guru untuk dapat menggunakan keterampilan dasar mengajar secara terpadu, serta menciptakan sistem lingkungan yang memungkinkan peserta didik dapat belajar secara efektif dan efisien untuk mendapatkan hasil yang maksimal. Hal ini nampak pada hasil belajar individu pra tindakan dengan perolehan nilai rata-rata 61,42 dengan persentase ketuntasan belajar 14 atau $42 \%$ dari 33 siswa dalam kelas.

Sehingga perlu adanya suatu pembenahan dalam pembelajaran. Pembelajaran yang dirasa bisa membuat siswa lebih bersemangat dalam pembelajaran adalah penggunaan metode problem solving dengan media gambar seri. Sesuai tingkat kebutuhan siswa yaitu operasional kongkrit adalah kebutukan menemukan pengetahuan baru melalui media sebenarya. Pemahaman kognitif dapat diperoleh siswa melalui pengalaman melakukan kegiatan atau sering dikenal dengan learning by doing yaitu belajar dengan melakukan. Untuk mengarahkan siswa melakukan pembelajaran dengan melakukan, salah satu caranya yaitu guru memberikan suatu materi pembelajaran yang bersifat problematik yang menuntut siswa untuk memecahan masalah.

Penerapan metode problem solving dengan media gambar seri memungkinkan siswa dalam mengidentifikasi masalah, memperoleh data, menyusun hipotesis dan mengaplikasikan konsep. Peningkatan dapat dilihat dari perolehan skor aktivitas siswa 
secara klasikal dan secara individu. Hal ini sesuai dengan teori metode problem solving menurut Oemar, (1980: 34) adalah suatu jenis cara belajar discovery dalam hal ini siswa, baik secara individu maupun kelompok berusaha memecahkan masalah/problem yang nyata. Pemecahan masalah secara kelompok dipandang lebih menguntungkan karena dapat memperoleh latar belakang yang lebih luas, dan dengan demikian lebih banyak memunculkan ide hipotesa dan kritik.

Menurut peneliti metode pemecahan masalah (problem solving method) yaitu metode yang dipakai oleh guru dalam kegiatan belajar mengajar untuk melatih siswa menghadapi berbagai masalah nyata, melalui proses dengan mencari data sampai kepada menarik kesimpulan. Sehingga mampu meningkatkan hasil belajar siswa.

Berdasarkan paparan data, diperoleh data penerapan metode problem solving dengan media gambar seri dalam meningkatkan hasil belajar siswa. Untuk mengukur peningkatan hasil belajar maka dilakukan penilaian siklus I yaitu dari penilaian aktivitas siswa, pada pertemuan 1 memperoleh nilai rata-rata klasikal 57 , pertemuan 2 memperoleh nilai rata-rata klasikal 63 dan pertemuan 3 memperoleh nilai rata-rata klasikal 63. Dari penilaian kerja kelompok, pada pertemuan 1 memperoleh nilai ratarata klasikal 64, pertemuan 2 memperoleh nilai rata-rata klasikal 66 dan pertemuan 3 memperoleh nilai rata-rata klasikal 69. Nilai hasil individu yang diperoleh nilai rata-rata 69 atau 64\% siswa tuntas dari 33 siswa. Hal ini menunjukkan bahwa hasil belajar siswa meningkat dari pra tindakan yang hanya memperoleh nilai rata-rata 61,42 atau $42 \%$ siswa tuntas. Karena hasil belajar belum mencapai ketuntasan yang direncanakan peneliti yaitu 75, maka dilanjutkan pada siklus II.

Meningkatnya hasil belajar dapat ditandai dengan perubahan tingkah laku dan kemampuan pada siswa. Peningkatan tingkah laku dialami oleh siswa dengan adanya perubahan mulai dari pra tindakan yang tidak pernah melakukan kerja kelompok, siklus I peneliti membiasakan siswa dalam kerja kelompok dan memanfaatkan media. Pada siklus II siswa sudah mampu melakukan kerja kelompok dengan memanfaatkan media.

Perubahan kemampuan siswa ditandai dengan peningkatan hasil belajar seperti yang telah dibahas di paragraf sebelumnya. Hal ini sesuai dengan pendapat Sudjana (1989: 22) menjelaskan bahwa hasil belajar adalah kemampuan-kemampuan yang dimiliki siswa setelah ia menerima pengalaman belajarnya. Pengalaman belajar tersebut dapat diperoleh di sekolah, rumah, dan masyarakat sekitar. Hasil belajar yang dibentuk diharapkan menjadi perubahan tingkah laku kearah yang lebih baik. Dengan demikian membuktikan bahwa terjadi peningkatan hasil belajar siswa yang ditandai dengan meningkatnya hasil belajar secara klasikal.

\section{Peningkatan Hasil Belajar IPS Melalui Metode Problem Solving dengan Media Gambar Seri Pada Siswa Kelas IV SDN Turi 01 Kota Blitar.}

Berdasarkan hasil penelitian yang telah dilaksanakan dapat diketahui bahwa terdapat peningkatan hasil belajar siswa. Hal tersebut diatas sesuai dengan pendapat Sapriya (2009: 12) menjelaskan bahwa pendidikan IPS di tingkat sekolah pada dasarnya bertujuan untuk mempersiapkan para peserta didik sebagai warga negara yang 
menguasai pengetahuan (knowlwdge), keterampilan (skill), sikap dan nilai (attitudes and values) yang dapat digunakan sebagai kemampuan untuk memecahkan masalah pribadi atau masalah sosial serta kemampuan mengambil keputusan dan berpartisipasi dalam berbagai kegiatan masyarakat agar menjadi warga negara yang baik.

Sehingga jika hasil belajar siswa meningkat, maka dapat disimpulkan metode pembelajaran yang dilakukan sudah baik. Hal ini telah sesuai dengan hasil kerja kelompok, nilai aktivitas siswa pada setiap pertemuan dan tes evaluasi pada setiap siklus. Hasil belajar pada pra tindakan dari 33 siswa yaitu 14 siswa (42\%) siswa tuntas belajar. Pada siklus I yaitu 21 siswa (64\%) dinyatakan tuntas belajar dan 12 siswa $(36 \%)$ belum tuntas belajar. Dari pra tindakan ke siklus I telah terjadi peningkatan ketuntasan belajar sebesar $22 \%$.

Pada pelaksanaan pembelajaran siklus II guru telah melakukan beberapa perbaikan untuk mengatasi kelemahan-kelemahan yang nampak pada siklus I. Hasil belajar pada siklus II adalah 32 siswa (97\%) yang tuntas belajar dan 1 siswa (3\%) yang belum tuntas belajar, dari siklus I ke siklus II telah terjadi peningkatan ketuntasan belajar sebesar 33\%. Berdasarkan hasil penelitian menggunakan metode problem solving dengan media gambar seri dapat meningkatkan hasil belajar siswa kelas IV SDN Turi 01. Hal ini ditandai dengan perubahan aktivitas dan kemampuan siswa dalam bekerja sama untuk memecahkan suatu permasalahan.

Berdasarkan pembahasan hasil belajar diatas sesuai dengan pendapat Sudjana (1989: 22) menjelaskan bahwa hasil belajar adalah kemampuan yang dimiliki siswa setelah ia menerima pengalaman belajarnya. Pengalaman belajar tersebut dapat diperoleh di sekolah, rumah, dan masyarakat sekitar. Hasil belajar yang dibentuk diharapkan menjadi perubahan tingkah laku kearah yang lebih baik.

\section{SIMPULAN}

Berdasarkan hasil penelitian tindakan kelas yang telah dilaksanakan, maka dapat disimpulkan bahwa:

1. Penerapan metode problem solving dengan media gambar seri dapat meningkatkan aktivitas belajar siswa. Aktifitas siswa dari pertemuan 1 siklus I ke pertemuan 2 siklus I meningkat dari 57 menjadi 62,8, Hal ini terjadi peningkatan sebesar 5,87. Dari pertemuan 2 siklus I ke pertemuan 3 siklus I meningkat dari 62,8 menjadi 62,9. Hal ini terjadi peningkatan sebesar 0,1. Dari pertemuan 3 siklus I ke pertemuan 1 Siklus II meningkat dari 62,9 menjadi 68. Hal ini terjadi peningkatan sebesar 5,1. Dari pertemuan 1 siklus II ke pertemuan 2 siklus II meningkat dari 68 menjadi 69. Hal ini terjadi peningkatan sebesar 1. Dari pertemuan 2 siklus II ke pertemuan 3 siklus II meningkat dari 69 menjadi 78. Hal ini meningkat sebesar 9. Hal ini menunjukkan terjadi peningkatan aktivitas belajar secara kontinyu.

2. Peningkatan hasil belajar siswa SDN Turi 01 Kota Blitar pada materi aktivitas ekonomi pada tahap pra tindakan masih sangat rendah dan belum mencapai ketuntasan hasil belajar. Karena hanya $42 \%$ siswa yang mampu mencapai batas standar KKM, yaitu 65. Hal ini disebabkan oleh cara mengajar guru kelas yang 
bersifat klasikal dan tidak menggunakan media pembelajaran, sehingga siswa merasa bosan dan malas untuk belajar. Dengan keadaan seperti ini nilai siswa menjadi rendah. Pada hasil belajar dari siklus I ke siklus II meningkat dari $64 \%$ menjadi 97\%, hal ini menunjukkan peningkatan hasil belajar secara klasikal sebesar $33 \%$. Dengan demikian metode pembelajaran problem solving mampu meningkatkan hasil belajar aktivitas ekonomi pada siswa kelas IV SDN Turi 01 Kota Blitar.

\section{SARAN}

Berdasarkan uraian dan simpulan tentang hasil penelitian melalui metode problem solving, maka diajukan beberapa saran sebagai berikut.

1. Dalam melaksanakan pembelajaran hendaknya guru menggunakan media pembelajaran untuk membantu siswa memahami materi yang dipelajari. Sehingga pembelajaran dapat berjalan dengan efektif dan bermakna bagi siswa.

2. Dalam pembelajaran hendaknya guru menggunakan metode dan media pembelajaran inovatif sehingga pembelajaran lebih bervariasai dan siswa akan merasa senang dalam mengikuti pembelajaran.

3. Berdasarkan hasil penelitian, hendaknya siswa lebih berani mengungkapkan ide, pendapat dan solusi pemecahan masalah tanpa takut salah dengan persepsinya.

4. Hendaknya siswa dapat bekerjasama dalam kelompok, sehingga pekerjaan lebih merata.

\section{DAFTAR RUJUKAN}

Akbar, Sa'dun, dkk. 2009. Prosedur Penyusunan Laporan dan Artikel. Yogyakarta: Cipta Media Aksara

Arikunto, Suharsimi. 2007. Penelitian Tindakan Kelas. Jakarta: PT Bumi Aksara.

Fathurrohman, Pupuh dan Sutikno, Sobry. 2009. Strategi Belajar Mengajar Melalui Penanaman Konsep Umum dan Konsep Islami. Bandung: Refika Aditama.

Oemar, Moh. 1980. Enquiry Discovery Problem Solving Dalam Pengajaran IPS. Jakarta: Depdiknas

Sagala, Syaiful. 2010. Konsep dan Makna Pembelajaran. Bandung: CV alfabeta

Sapriya. 2009. Pendidikan IPS. Bandung: PT Remaja Rosdakarya

Sudjana, Nana. 1989. Penilaian Hasil Proses Belajar Mengajar. Bandung: Remaja Rosda karya

Suharjo. 2006. Mengenal Pendidikan Sekolah Dasar. Jakarta: Depdiknas 